\title{
Pengaruh Iklim Terhadap Peluang Umur Nyamuk Mansonia spp di Daerah Endemis Filariasis di Kabupaten Kapuas
}

\author{
Muhammad Rasyid Ridha $^{1}$, Juhairiyah ${ }^{1}$, Deni Fakhrizal ${ }^{1}$ \\ 1 Balai Litbang P2B2 Tanah Bumbu, Jalan. Lokalitbang, Kawasan Perkantoran Pemda Kabupaten Tanah Bumbu, \\ Kalimantan Selatan, Kotak Pos 666
}

Info Artikel : Diterima Februari 2018 ; Disetujui April 2018 ; Publikasi Oktober 2018

\begin{abstract}
ABSTRAK
Latar belakang: Filariasis merupakan penyakit menular menahun yang disebabkan oleh cacing filaria jenis Wuchereria bancrofti, Brugia malayi dan Brugia timori melalui nyamuk sebagai vektor. Penelitian ini bertujuan untuk mengetahui pengaruh iklim terhadap peluang hidup di alam nyamuk Mansonia spp. di daerah endemis filariasis di Kelurahan Mandomai, Kabupaten Kapuas

Metode: . Koleksi nyamuk dengan metode human landing collection di dalam dan diluar rumah, nyamuk yang tertangkap setelah di identifikasi dilakukan pembedahan. Pembedahan abdomen nyamuk untuk mengetahui paritas. Data iklim dan curah hujan diambil dari data BMKG.

Hasil: Hasil penelitian diketahui Aktivitas menghisap darah Ma. uniformis di luar rumah banyak tertangkap pada pukul 21.00-22.00 dan di dalam rumah pada pukul 22.00-23.00. Aktivitas Ma. dives banyak tertangkap pada pagi hari yaitu pukul 04.00-05.00 di luar rumah, sedangkan di dalam rumah paling banyak pukul 23.0024.00. Aktivitas Ma. annulata di luar rumah paling banyak tertangkap pada pukul 18.00-19.00 dan di dalam rumah paling banyak tertangkap pada pukul 19.00-20.00. Kepadatan tertinggi per hari (MBR) dan perjam (MHD) pada Ma. annulata di luar rumah, sedangkan yang terendah pada Ma. dives. Berdasarakan data dari BMKG dan pengukuran di lapangan, suhu di daerah Kelurahan Mandomai dari bulan juli sampai desember berkisar antara $28^{\circ} \mathrm{C}$, dimana kelembaban dan curah hujan tertinggi terjadi pada bulan Desember. Peluang hidup di alam nyamuk Ma. uniformis 4,4 hari, Ma. dives 1,3 hari dan Ma. annulata 32,2 hari. Hasil uji statistik diketahui ada pengaruh indeks curah hujan dan kelembaban dengan Peluang hidup di alam Ma. annulata

Simpulan: Ditemukannya nyamuk Mansonia yang berperan sebagai vektor dengan peluang hidup di alam lebih dari 14 hari sehingga iklim di Kelurahan Mandomai mendukung perkembangan nyamuk sebagai vektor.
\end{abstract}

Kata kunci: Peluang hidup; Iklim; Mansonia; Filariasis

\section{ABSTRACT}

Title: Climate Influence on Mansonia spp Mosquito Age Spend in Endemic Filariasis Region in Kapuas District Background: Filariasis is a chronic infectious disease caused by filarial worms, i.e. Wuchereria bancrofti, Brugia malayi and Brugia timori species and transmitted by mosquitoes as vectors. Aim this study to determine the effect of climate on the chances of living in the nature of mosquito Mansonia spp. in the filariasis endemic area of Mandomai Village, Kapuas District

Methods: Mosquitoes are collected by human landing collection of people in and out the home, abdominal surgery mosquitoes to know parity. Climate dan rainfall index are taken from $B M K G$.

Results: The result showed activity of blood sucking outdoors caught at 21.00-22.00 and indoor 22.00-23.00 for Ma. uniformis. Caught in the morning at 04.00-05.00 outside, while indoor 23.00-24.00 for Ma. dives. Outdoors Activity caught at most at 18.00-19.00 and indoor at 19.00-20.00 for Ma. annulata. The highest density man bitting fate and man hour density in Ma. annulata is outdoors, while the lowest on Ma. dives. Based on data from BMKG and field measurements, the temperatures in the Mandomai Urban Village from July to December ranged from $28^{\circ}$ C, while humidity and the highest rainfall occurred in December. Longevity of mosquito 4.4 days for Ma. uniformis, 1.3 days for Ma. dives and 32.2 days Ma. annulata. The results of statistical test known to have influence of temperature dan index of rainfall with longevity of Ma. uniformis and Ma. dives. 
Conclusion: The discovery of Mansonia mosquito that acts as a vector with longevity more than 14 days, so that the climate in Mandomai village supports the development of mosquitoes as vectors

Keywords: Longevity; Climate; Mansonia; Filariasis

\section{PENDAHULUAN}

Filariasis merupakan penyakit menular menahun yang disebabkan oleh cacing filaria jenis Wuchereria bancrofti, Brugia malayi dan Brugia timori yang endemis di daerah tropis dan subtropis. ${ }^{1}$ Cacing filaria hidup di saluran dan kelenjar getah bening menyebabkan demam berulang, peradangan saluran getah bening yang retrograd, dan peradangan kelenjar. Walaupun tidak mengakibatkan kematian, pada stadium lanjut penyakit ini dapat menyebabkan cacat fisik permanen dan mempunyai dampak sosial ekonomi. ${ }^{2}$ Nyamuk berperan sebagai vektor dalam penularan filariasis. Jenis nyamuk Aedes, Culex, Mansonia, Anopheles dan Armigeres telah dilaporkan dapat berperan sebagai vektor. Persyaratan nyamuk menjadi vektor antara lain adalah umur nyamuk, kepadatan, ada kontak dengan manusia, tahan terhadap parasit dan ada sumber penularan. ${ }^{3}$

Kabupaten Kapuas merupakan salah satu daerah endemis filariasis dengan jumlah kasus tertinggi di Provinsi Kalimantan Tengah. Jumlah kasus filariasis masih ditemukan sampai dengan tahun 2011 sebanyak 16 kasus. Sejak tahun 2008 Kabupaten Kapuas telah melakukan pengobatan massal dan berakhir tahun 2012. Transmission assesment survei (TAS) sebagai survey evaluasi untuk mengetahui adanya penularan baru dilakukan kepada 1542 anak sekolah dasar (SD) pada tahun 2013. Hasil survey TAS ditemukan 17 anak positif filariasis. ${ }^{4}$

Kabupaten Kapuas berbatasan dengan Kabupaten Barito, Pulang Pisau, dan Barito Selatan. Kabupaten Kapuas pada umumnya termasuk daerah beriklim tropis dan lembab dengan temperatur berkisar antara $21-23^{\circ} \mathrm{C}$ dan maksimal mencapai $36^{\circ} \mathrm{C}$. Curah hujan terbanyak jatuh pada Bulan Maret, berkisar di antara 223-604 mm tiap tahun. ${ }^{5}$ Hujan menyebabkan naiknya kelembaban nisbi udara dan curah hujan yang tinggi mengakibatkan banyak genangan air yang muncul secara tiba-tiba, genangan air ini yang digunakan nyamuk sebagai tempat perkembangbiakan dan menambah jumlah tempat perkembangbiakan (breeding places) sehingga menyebabkan peningkatan insiden penyakit akibat nyamuk dan berpengaruh terhadap daya tahan hidup nyamuk/vektor.

Peningkatan suhu akan mempengaruhi perubahan bionomik atau perilaku menggigit dari populasi nyamuk, angka gigitan rata-rata meningkat (biting rate), kegiatan reproduksi nyamuk berubah ditandai dengan perkembangbiakan nyamuk yang semakin cepat dan masa kematangan parasit dalam tubuh nyamuk akan semakin pendek. ${ }^{5}$

Salah satu syarat nyamuk menjadi vektor filariasis yaitu harus mempunyai umur yang relatif harus lebih panjang dari masa inkubasi ekstrinsik, hal tersebut karena larva filaria memerlukan waktu $8-12$ hari untuk menjadi larva infektif. ${ }^{6}$ Menurut penelitian yang dilakukan oleh Yulius, dkk di Kepulauan Yapen, menyatakan bahwa suhu dan kelembaban berpengaruh terhadap kebiasaan menggigit dan umur nyamuk sehingga mikrofilaria dalam tubuh nyamuk mempunyai waktu yang cukup untuk tumbuh menjadi larva infektif L3. ${ }^{7}$ Di Kabupaten Kapuas, belum pernah dilakukan penelitian terhadap peluang umur nyamuk, sehingga perlu diketahui pengaruh suhu, kelembaban dan indeks curah hujan terhadap peluang umur nyamuk di daerah endemis filariasis di Kabupaten Kapuas.

\section{MATERI DAN METODE}

Penelitian dilakukan pada bulan Juli Desember 2015 di Kelurahan Mandomai, Kecamatan Kapuas Barat, Kabupaten Kapuas, Provinsi Kalimantan Tengah. Berdasarkan data dari Badan Meteorologi, Klimatologi dan Geofisika (BMKG) awal musim penghujan di Kabupaten kapuas diperkirakan pada bulan Oktober 2015, sehingga penelitian dilakukan dimulai pada bulan Juli 2015 untuk bisa mewakili musim hujan dan kemarau. Jenis penelitian ini merupakan penelitian observasional analitik dengan rancangan cross sectional. Kegiatan yang dilakukan yaitu penangkapan nyamuk, identifikasi dan pembedahan nyamuk. Penangkapan nyamuk dilakukan dengan metode umpan orang atau human landing collection (HLC). Penangkapan nyamuk dilakukan di dalam dan di luar rumah dari jam $18.00-06.00$ WITA. Suhu dan kelebaban dicatat setiap jam penangkapan. Nyamuk yang tertangkap melalui HLC di identifikasi di bawah mikroskop stereo menggunakan kunci identifikasi morfologi bergambar nyamuk Mansonia (O'Connor dan Soepanto 2000). Pembedahan nyamuk untuk mengetahui paritas, parus jika pernah bertelur dan nuliparus jika belum pernah bertelur. Pembedahan nyamuk dilakukan dengan menggunakan jarum seksi di bawah mikroskop. Data jumlah curah hujan dan hari hujan di dapat dari badan Badan Meteorologi, Klimatologi, dan Geofisika (BMKG) dari bulan JuliDesember 2015.

Data curah hujan kemudian dihitung Indeks Curah Hujan (ICH) didapat dengan menggunakan rumus:

$$
\mathrm{ICH}=\frac{\text { Jumlah curah hujan } \mathrm{x} \text { Hari hujan }}{\text { Lama hari pada bulan yang bersangkutan }} \mathrm{X} \mathrm{100 \%}
$$


Kepadatan populasi nyamuk (Man hour density dan Man bitting rate) diperoleh dengan rumus (WHO 2013):

Man hour density $(\mathrm{MHD})=\frac{\text { Jumlah nyamuk ditangkap dengan umpan orang }}{\text { Lama penangkapan/jam x Jumlah penangkapan } \mathrm{x} \text { jumlah waktu penangkapan }}$

Man bitting rate $(\mathrm{MBR})=\frac{\text { Jumlah nyamuk ditangkap dengan umpan orang }}{\text { Lama penangkapan / Jam x Jumlah malam x Jumlah umpan orang }}$

Peluang hidup nyamuk setiap hari yang dinyatakan dalam $\%$ yang diperoleh dari suatu perhitungan matematis dengan mengetahui proporsi parus dan siklus gonotropik (Davidson 1954).

$$
P=b \sqrt{ } d
$$

P : peluang hidup nyamuk setiap hari

$\mathrm{b}$ : siklus gonotropik (hari)

$\mathrm{d}$ : Parus rate (porporsi nyamuk parus $=\%$ )

Hasil pengukuran : Peluang hidup nyamuk setiap hari ( \% )

Umur relatif nyamuk di populasi adalah perkiraan umur nyamuk di populasi yang dinyatakan dalam hari, yang diperoleh melalui suatu perhitungan matematis dengan melakukan perhitungan setelah diketahuinya peluang hidup nyamuk setiap hari (Davidson 1954; Drapper and Davidon 1952).

$$
\text { Umur relatif di populasi }=\frac{1}{-\log e^{p}}
$$

$\log \mathrm{e} \quad:$ : Bilangan matematis tertentu

$\mathrm{p} \quad$ : Peluang hidup nyamuk

Data umur nyamuk, suhu, kelembaban dan data yang didapat dari BMKG dianalisis menggunakan regresi linear untuk mengetahui hubungan antar variabel yang ingin diketahui. Persamaan yang digunakan :

$\mathrm{Y}=\mathrm{a}+\mathrm{bX}$

$\mathrm{Y}:$ Variabel dependent

$\mathrm{X}$ : Variabel independent

a : konstanta

$\mathrm{b}:$ koefisien regresi

\section{HASIL DAN PEMBAHASAN \\ Fluktuasi Nyamuk}

Aktivitas menghisap darah Ma. uniformis di luar rumah banyak tertangkap pada pukul 21.00-22.00 dan di dalam rumah pada pukul 22.00-23.00. Aktivitas $M a$. dives banyak tertangkap pada pagi hari yaitu pukul 04.00-05.00 di luar rumah, sedangkan di dalam rumah paling banyak pukul 23.00-24.00. Aktivitas Ma. annulata di luar rumah paling banyak tertangkap pada pukul 18.00-19.00 dan di dalam rumah paling banyak tertangkap pada pukul 19.0020.00. (Gambar 1). Hasil penelitian tersebut sama dengan yang ditemukan di Kota Besi, Kotawaringin Timur bahwa perilaku Ma. uniformis banyak ditemukan pada pukul 21.00- 22.00 dan lebih banyak ditemukan di dalam rumah. ${ }^{8}$ Hasil penelitian ini berbeda dengan penelitian yang dilakukan oleh Supriyono dkk (2017) di Kabupaten Balangan, Kalimantan Selatan yang menyatakan Ma. uniformis merupakan nyamuk yang paling banyak tertangkap di dalam rumah yaitu sebesar $37.99 \%$ sedangkan nyamuk Ma. dives banyak tertangkap di luar rumah yaitu sebesar $56.80 \%$. Puncak kepadatan nyamuk Ma.uniformis ini mengisap darah orang di dalam rumah terjadi pada pukul 18:00-18:45, sedangkan di luar rumah pada pukul 20:00-20:45. Ma. Dives memiliki puncak kepadatan pada pukul 19:00-19:45. ${ }^{9}$ Beberapa hasil penelitian tersebut menggambarkan bahwa perilaku nyamuk bersifat lokal spesifik atau setiap daerah mempunyai perilaku yang berbeda. Hasil Penelitian diketahui perilaku nyamuk Mansonia spp secara keseluruhan memiliki perilaku suka menghisap darah di luar rumah. Pekerjaan masyarakat sebagian adalah petani karet dan umumnya menyadap karet mulai pukul $02.00-07.00$ pagi sehingga berisiko terhisap nyamuk Mansonia spp. Sedangkan pada siang hari jika tidak musim padi mereka memancing ikan di sungai.

\section{Kepadatan Nyamuk}

Kepadatan nyamuk dihitung berdasarkan kepadatan nyamuk yang hinggap pada setiap orang per jam (Man Hour Desnity) dan kepadatan nyamuk yang hinggap pada setiap orang perhari (Man Bitting Rate). Tabel 1 menunjukkan kepadatan Manasonia spp yang tertangkap di dalam dan di luar rumah. Kepadatan tertinggi per hari (MBR) dan perjam (MHD) pada Ma. annulata di luar rumah, sedangkan yang terendah pada Ma. dives.

Mansonia spp diketahui berperan sebagai vektor filariasis, Ross river virus, Murray Valley encephalitis ${ }^{8}$, Kuinjin virus ${ }^{8}$, edge hill virus dan virus rift valley fever. ${ }^{10}$ Beberapa spesies Mansonia dilaporkan sebagau vektor di Kalimantan yaitu Mansonia bonneae (diptera: culicidae) sebagai vektor utama filariasis yang disebabkan oleh Brugia malayi nonperiodik di daerah penduduk asli Dayak di 
Kalimantan Timur ${ }^{10}$ dan Ma. uniformis sebagai vektor filariasis tipe rawa di Kabupaten Batola, Kalimantan Selatan. ${ }^{10}$ Mansonia uniformis, Ma. dives dan Ma.bonneae menjadi vektor utama penularan B.malayi tipe subperiodik dan periodik nokturnal di beberapa daerah di Thailand Bagian selatan dan Nakhon Si Thammarat, Narathiwat Surat Thani, Pattani, Phattalung, and Provinsi Yala, sedangkan yang menjadi vektor sekunder adalah Ma. dives, $M a$. annulata, dan Ma. annulifera.

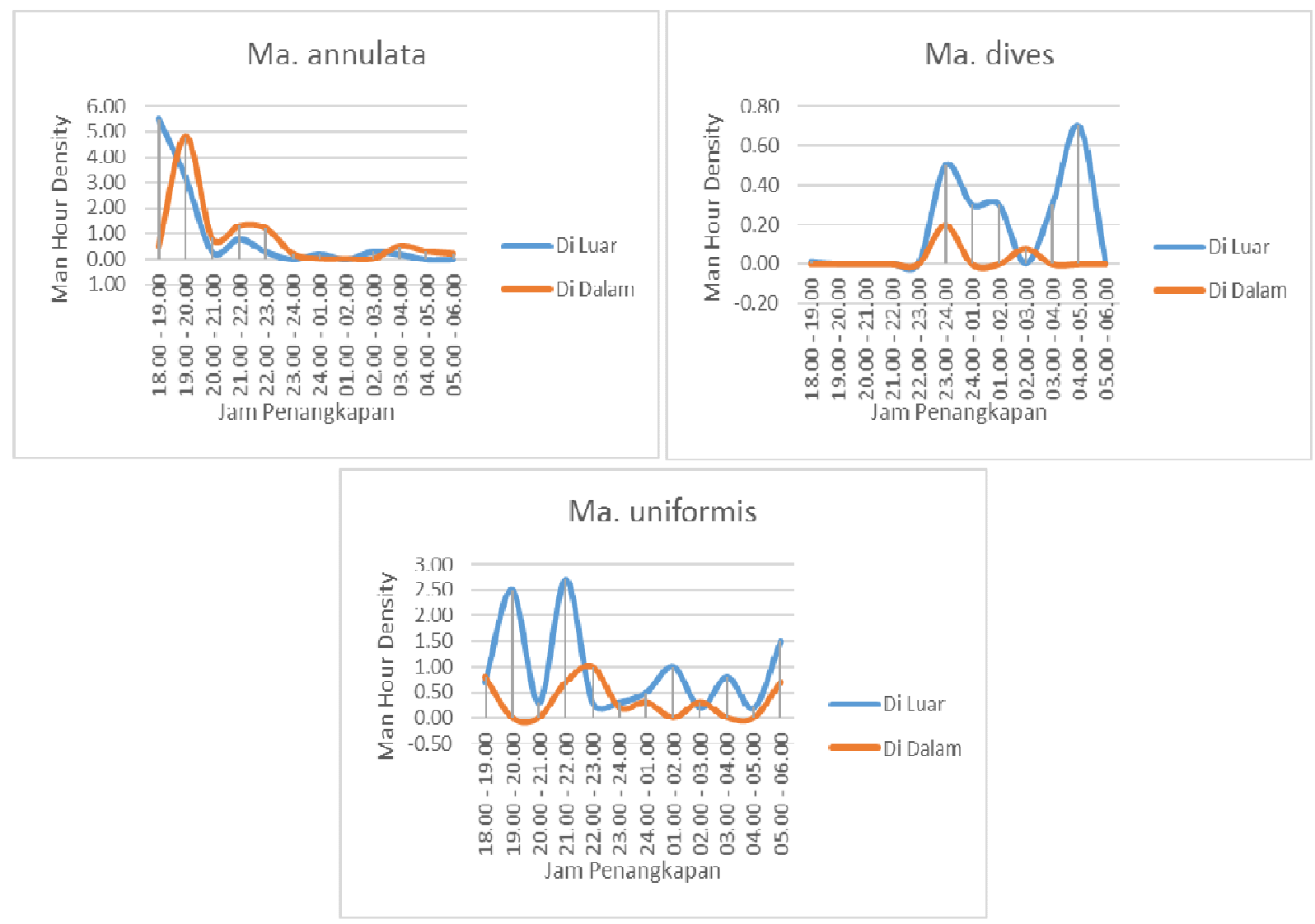

Gambar 1. Kepadatan rata-rata nyamuk (man hour density) Ma. uniformis, Ma. dives,dan Ma. annulata yang tertangkap dari Juli - Desember di Kelurahan Mandomai, Kabupaten Kapuas

Beberapa spesies nyamuk yang menjadi vektor utama maupun vektor sekunder di kawasan Selatan Thailand ini juga ditemukan di Kabupaten Kapuas. Berdasarkan laporan organisasi kesehatan dunia atau World Health Organization (WHO), vektor filariasis di daerah endemis filarisis di Bagian Asia Selatan yang disebabkan oleh B.malayi tipe periodik adalah An.anthropophagus, An.barbirostris,
An.campestris, An.donaldi, An.kweiyangensis, An.sinensis, An.nigerimus, Ma.annulata, Ma.annulifera, Ma.uniformis, Ma.bonneae, Ma. dives Ma.Indiana, Ae.kiangensis dan Ae. togoi. Sedangkan vektor untuk B.malayi tipe subperiodik nokturna adalah Ma. annulata, Ma. bonneae, Ma. dives, dan Ma. uniformis. ${ }^{3,11}$

Tabel 1. Kepadatan Mansonia spp yang tertangkap di dalam dan di luar rumah

\begin{tabular}{lcccc}
\hline \multirow{2}{*}{ Spesies } & \multicolumn{2}{c}{ MHD } & \multirow{2}{*}{ MHD } & \multirow{2}{*}{ MBR } \\
\cline { 2 - 3 } & Di Dalam & Di Luar & & \\
\hline Ma. uniformis & 0,05 & 0,14 & 0,19 & 1,52 \\
Ma. dives & 0,00 & 0,05 & 0,05 & 0,37 \\
Ma. annulata & 0,27 & 0,30 & 0,56 & 4,5 \\
\hline
\end{tabular}

Keterangan : MHD : Man Hour Dnsity, MBR : Man Bitting Rate 
Tabel 2. Data suhu, kelemababan dan curah hujan di Desa Mandomai, Kecamatan Kapuas Barat, Kabupaten Kapuas, Provinsi Kalimantan Tengah selama bulan Juli-Desember 2015

\begin{tabular}{lcccccc}
\hline & Juli & Agustus & September & Oktober & November & Desember \\
\hline Suhu & $28,70^{\circ} \mathrm{c}$ & $28,62^{\circ} \mathrm{c}$ & $28,62^{\circ} \mathrm{c}$ & $28,56^{\circ} \mathrm{c}$ & $28,20^{\circ} \mathrm{c}$ & $27,30^{\circ} \mathrm{c}$ \\
Kelembaban & $79,10 \%$ & $80,17 \%$ & $80,33 \%$ & $84,50 \%$ & $85,25 \%$ & $87,67 \%$ \\
Curah Hujan & 28,42 & 28,47 & 28,27 & 90,87 & 119,00 & 239,35 \\
& $\mathrm{~mm} / \mathrm{hari}$ & $\mathrm{mm} / \mathrm{hari}$ & $\mathrm{mm} / \mathrm{hari}$ & $\mathrm{mm} / \mathrm{hari}$ & $\mathrm{mm} / \mathrm{hari}$ & $\mathrm{mm} / \mathrm{hari}$ \\
\hline
\end{tabular}

Tabel 3. Peluang hidup nyamuk Mansonia di alam

\begin{tabular}{lccccccc}
\hline \multicolumn{1}{c}{ Spesies } & \multicolumn{5}{c}{ Peluang Hidup Di Alam (hari) } & \multirow{2}{*}{ Rata-rata } \\
\cline { 2 - 7 } Nyamuk & Juli & Agustus & September & Oktober & November & Desember & \\
\hline Man uniformis & 40,23 & 34,22 & 33,56 & 19,34 & 20,33 & 38,21 & 30,98 \\
Ma. dives & 44,21 & 42,1 & 36,2 & 11,3 & 8,12 & 39,45 & 30,23 \\
Ma. annulata & 0 & 0 & 14,1 & 17,2 & 20,22 & 37,23 & 14,79 \\
\hline
\end{tabular}

Berdasarakan data dari BMKG dan pengukuran di lapangan, suhu di daerah Kelurahan Mandomai dari bulan juli sampai desember berkisar antara $28^{\circ} \mathrm{C}$, sedangkan Kelembaban dan curah hujan tertinggi terjadi pada bulan Desember (Tabel 2). Faktor ekologi berupa suhu dan kelembaban juga dapat mempengaruhi kepadatan nyamuk vektor sehingga dapat meningkatkan resiko penularan filariasis di suatu daerah. ${ }^{12}$, 13 Jarak tempat perkembangbiakan nyamuk dengan pemukiman juga akan mempengaruhi penularan filariasis, karena nyamuk dewasa akan segera mencari darah untuk pematangan telur. ${ }^{14}$ Hasil penelitian di Kabupaten Pekalonganuasin juga mendapatkan bahwa sebagian besar kasus positif filariasis tinggal di dekat tempat perkembangbiakan nyamuk vektor. ${ }^{15}$

Penularan filariasis dipengaruhi oleh beberapa faktor, diantaranya adanya penderita positif mikrofilaria, kepadatan vektor penular, perilaku masyarakat serta faktor ekologi yang mempengaruhi kepadatan vektor. ${ }^{16,17}$ Hasil penelitian menunjukkan. Karakteristik wilayah yang ditemukan di daerah penelitian mendukung untuk perkembangbiakan Mansonia spp. Karakteritik wilayah yang ditemukan berupa rawa dan persawahan serta dekat dengan lahan gambut. Perindukan masonia banyak ditemukan pada rawa dan danau yang mempunyai tanaman air. ${ }^{4}$

\section{Peluang hidup nyamuk di Alam}

Data peluang hidup nyamuk mansonia dapat dilihat pada tabel 3. Nyamuk Mansonia yang mempunyai peluang hidup paling rendah adalah Ma. Annulata dengan rata-rata 14,79 sedangkan Ma. uniformis dan Ma. dives mempunyai rata-rata peluang hidup yang hampir sama (tabel. 3).

Data peluang hidup nyamuk kemudian dianalisis menggunakan regresi linear dengan suhu kelembaban dan curah hujan. Hasil analisis dapat dilihat pada tabel 4. Berdasarkan tabel 4 diketahui bahwa kelembaban dan indeks curah hujan (ICH) mempengaruhi peluang hidup nyamuk Ma. annulata di alam $(\mathrm{p}<0,05)$.
Tabel 4. Pengaruh suhu, kelembaban dan indeks curah hujan terhadap Ma. uniformis, Ma. dives dan Ma. annulata.

\begin{tabular}{lccc}
\hline \multirow{2}{*}{ Variabel } & \multicolumn{3}{c}{ Spesies nyamuk } \\
\cline { 2 - 4 } & $\begin{array}{c}\text { Ma. } \\
\text { uniformis }\end{array}$ & $\begin{array}{c}\text { Ma. } \\
\text { dives }\end{array}$ & $\begin{array}{c}\text { Ma. } \\
\text { annulata }\end{array}$ \\
\hline Suhu & 0,449 & 0,672 & 0,092 \\
Kelembaban & 0,941 & 0.678 & $0,049^{*}$ \\
ICH & 0,739 & 0,337 & $0,014^{*}$ \\
\hline
\end{tabular}

Ket : ICH : indeks curah hujan, * : Terdapat pengaruh

Umur nyamuk berpengaruh terhadap kemampuan lamanya hidup di alam, hal ini berhubungan dengan kemampuan perkembangan mikrofilaria di dalam tubuh nyamuk, sehingga nyamuk tersebut berpeluang sebagai vektor. Nyamuk dapat berperan sebagai vektor apabila memenuhi persyaratan sebagai berikut : (a) Nyamuk vektor mempunyai kontak terhadap manusia cukup tinggi, dalam hal ini dinyatakan dalam kepadatan menggigit orang (MBR). (b) Nyamuk vektor merupakan spesies yang jumlahnya selalu dominan bila dibandingkan dengan spesies lainnya. (c) Populasi spesies yang bersangkutan umumnya mempunyai umur cukup panjang, yang dalam persen nyamuk. (d) Di tempat lain ternyata spesies tersebut telah dikonfirmasi sebagai vektor. ${ }^{6}$

Kalimantan merupakan daerah endemis $B$. malayi dan $70 \%$ penderita di Indonesia filriasis B.malayi. Masa inkubasi B. malayi di dalam tubuh nyamuk berkisar 7-14 hari sehingga jika umur nyamuk lebih dari 13 hari akan memberikan peluang nyamuk menjadi vektor. Umur nyamuk di alam dipengaruhi oleh suhu dan kelembaban, indeks curah hujan serta ada tidaknya predator. Penelitian di Brazil menyebutkan nyamuk mempunyai peluang hidup lebih lama dua kali di musim hujan dibandingkan di musim kemarau. Penelitian lain di Desa Lare Bagian barat daya Ethiophia menyebutkan umur An. gambie s.l di Bulan Mei 4,7 hari, sedangkan Bulan Juli, umurnya bisa mencapai 9,4 hari $^{18}$, sedangkan di Desa Seka-Chekorsa pada spesies yang sama di Bulan Juli umurnya bisa mecapai 12.5 hari. ${ }^{19}$ Suhu ideal 
perkembangan nyamuk berkisar $24-29{ }^{\circ} \mathrm{C}$, jika suhu terlalu tinggi $\left(>37^{\circ} \mathrm{C}\right)$ maka nyamuk akan mati. ${ }^{20}$

\section{SIMPULAN}

Kelembaban dan indeks curah hujan mempunyai pengaruh terhadap umur nyamuk di Kelurahan Mandomai dan dapat mendukung perkembangan nyamuk sebagai vektor karena ditemukan nyamuk Mansonia yang berumur lebih dari 14 hari, sedangkan suhu tidak ditemukan pengaruh.

\section{DAFTAR PUSTAKA}

1. Shriram AN, Krishnamoorthy K, Vijayachari P. Diurnally subperiodic filariasis among the Nicobarese of Nicobar district - epidemiology, vector dynamics \& prospects of elimination. Indian Journal Medical Research 2015, 141(5): 598-607.

2. Mues KE. Assessment and management of chronic lymphatic filariasis morbidity among endemic populations. University in partial fulfillment of the requirements for the degree of Doctor of Philosophy in Epidemiology; 2014.

3. World Health Organization. Lymphatic Filariasis Practical Entomology. Global Programme to Eliminate Lymphatic Filariasis. Geneva: Switzerland; 2013.

4. Ridha MR. Vektor potensial Filariasis dan habitatnya di Desa Mandomai Kabupaten Kapuas Provinsi Kalimantan Tengah. Tesis. Institut Pertanian Bogor; 2016.

5. Mardiana, Perwitasari D. Insiden Malaria Dan Pola Iklim Di Kabupaten Kapuas Propinsi Kalimantan Tengah dan Kabupaten Sumba Barat Propinsi Nusa Tenggara Timur, Indonesia Tahun 2005 - 2009. Jurnal Ekologi Kesehatan 2014, 13(1):59-70.

6. Krishnamoorthy $\mathrm{K}$, Subramanian S, Van Oortmarssen GJ, Habbema JDF, Das PK. Vector survival and parasite infection: the effect of Wuchereria bancrofti on its vector Culex quinquefasciatus. Parasitology 2004, 129(1):4350 .

7. Sarunguyulius Y, Paiting S, Setiani O. Faktor risiko lingkungan dan kebiasaan penduduk berhubungan dengan kejadian filariasis di Distrik Windesi Kabupaten Kepulauan Yapen Provinsi Papua. Jurnal Kesehatan Lingkungan Indonesia 2012, 11(1): 76-81.

8. Setiawan B, Soeyoko S, Satoto TB. Epidemiologi Filariasis Limfatik di Kecamatan Kota Besi, Kabupaten Kotawaringin Timur Provinsi Kalimantan Tengah. Spirakel 2012, 2: 25-31.

9. Supriyono, Supriyono Tan, Suriyani, Hadi UK. Perilaku nyamuk mansonia dan potensi reservoar dalam penularan filariasis di Desa Gulinggang Kabupaten Balangan Provinsi Kalimantan Selatan. Aspirator 2017, 9(1): 1-10.
10. Pepin M, Bouloy M, Bird BH, Kemp A, Paweska J. Rift Valley fever virus ( Bunyaviridae: Phlebovirus ): an update on pathogenesis, molecular epidemiology, vectors, diagnostics and prevention. Veterinary Reserch 2010, 41(6): 61-68.

11. World Health Organization. Global programme to eliminate lymphatic filariasis: Managing morbidity and preventing disability. World Health Organization. Geneva; 2013.

12. Wu Y, Preston G, Bianco AE. Chitinase is stored and secreted from the inner body of microfilariae and has a role in exsheathment in the parasitic nematode Brugia malayi. Molecular and Biochemical Parasitology 2008 161(1): 55-62.

13. Gunathilaka N, Abeyewickreme W, Hapugoda M, Wickremasinghe R. Species Composition and Diversity of Malaria Vector Breeding Habitats in Trincomalee District of Sri Lanka. Biomed Research International 2015, 15: 1-10.

14. Verdonschot PFM, Besse-Lototskaya AA. Flight distance of mosquitoes (Culicidae): A metadata analysis to support the management of barrier zones around rewetted and newly constructed wetlands. Limnologica - Ecology Management of Inland Waters 2014, 45: 69-79.

15. Utami IW, Cahyati WH. Lingkungan tempat Perindukan Nyamuk Culex quinquefasciatus Di Sekitar Penderita Filariasis. HIGEIA 2017 1(1): $1-7$.

16. Palaniyandi $\mathrm{M}$, Anand $\mathrm{P}$, Pavendar $\mathrm{T}$. Environmental risk factors in relation to occurrence of vector borne diseaseepidemics: Remote sensing and GIS for rapid assessment, picturesque, and monitoring towards sustainable health. International Journal of Mosquito Research 2017, 4(3): 9-20.

17. Coutts SP, King JD, Pa'au M, Fuimaono S, Roth J, King MR, et al. Prevalence and risk factors associated with lymphatic filariasis in American Samoa after mass drug administration. Tropical Medical Health 2017, 45(1): 22-30.

18. Taye B, Seid M, Gindaba A. Entomological study on species composition, behavior, longevity and probability of surviving sporogony of Anopheles mosquitoes in Lare District, Ethiopia. Journal Parasitology Vector Biology 2017, 9(9):137-45.

19. Taye B, Lelisa K, Emana D, Asale A, Yewhalaw D. Seasonal dynamics, longevity, and biting activity of anopheline mosquitoes in Southwestern Ethiopia. Journal of Insect Science 2016, 16(1): 6-14.

20. Mordecai EA, Paaijmans KP, Johnson LR, Balzer C, Ben-Horin T, de Moor E, et al. Optimal temperature for malaria transmission is dramatically lower than previously predicted. Thrall P, editor. Ecology Letter 2013, 16(1): 22-30. 